\title{
KOMITE AUDIT SEBAGAI PEMODERASI PENGARUH WORKLOAD DAN MASA PERIKATAN AUDIT PADA KUALITAS AUDIT
}

\author{
Theresia Julina Rusli ${ }^{1}$ \\ I Dewa Nyoman Wiratmaja ${ }^{2}$ \\ ${ }^{1}$ Fakultas Ekonomi dan Bisnis Universitas Udayana (Unud), Bali, Indonesia \\ e-mail: theresiajulina@gmail.com \\ ${ }^{2}$ Fakultas Ekonomi dan Bisnis Universitas Udayana (Unud), Bali, Indonesia
}

\begin{abstract}
ABSTRAK
Penelitian ini bertujuan untuk menguji pengaruh workload dan masa perikatan audit terhadap kualitas audit, dan komite audit sebagai variabel moderasi. Objek penelitian dalam penelitian ini adalah perusahaan manufaktur yang terdaftar di Bursa Efek Indonesia (BEI). Sebanyak 31 sampel data diperoleh melalui metode pemilihan sampel purposive sampling. Pengujian hipotesis dalam penelitian ini menggunakan teknik analisis Moderated Regression Analysis (MRA). Hasil pengujian hipotesis menunjukkan bahwa variabel workload berpengaruh negatif terhadap kualitas audit. Masa perikatan audit berpengaruh positif pada kualitas audit. Variabel komite audit dalam interaksinya dengan workload bersifat memperlemah pengaruh negatif workload terhadap kualitas audit. Variabel komite audit dalam interaksinya dengan masa perikatan audit bersifat memperlemah pengaruh positif masa perikatan audit terhadap kualitas audit.
\end{abstract}

Kata Kunci: Workload, masa perikatan audit, komite audit, kualitas audit

\begin{abstract}
This research aims to find empirical evidence about the impact of workload and audit tenure on audit quality and using audit committee as a moderating variable. This research focused on manufacturing companies that listed on the Indonesia Stock Exchange. Sample was collected using purposive sampling method and resulted 31 companies as a final sample. The data are analyzed by using Moderated Regression Analysis (MRA). The results of this research indicate that the workload has a negative impact on audit quality. Audit tenure has a positive impact on audit quality. Audit committee reduces the negative impact of workload on audit quality. And audit committee reduces the positive impact of audit tenure on audit quality
\end{abstract}

Keywords: Workload, audit tenure, audit committee, audit quality

\section{PENDAHULUAN}

Pemilik perusahaan atau principal memberikan kepercayaan dan mendelegasikan wewenang kepada manajemen selaku agent dalam pembuatan keputusan mengenai kegiatan operasional perusahaan. Hasil dari kegiatan operasional perusahaan tersebut pada akhir periode perlu dilaporkan melalui laporan keuangan sebagai bentuk pertanggungjawaban manajemen terhadap para stakeholders.

Pemisahan fungsi pengelolaan serta kepemilikan dalam perusahaan akan mengakibatkan munculnya perbedaan kepentingan antara pemilik perusahaan dan manajemen sehingga dapat memicu timbulnya kecurangan misalnya munculnya praktik earnings management oleh manajemen karena adanya kecenderungan setiap pihak untuk mencapai tingkat kemakmuran yang dikehendakinya (Salno dan Baridwan, 2000). Diperlukan peran pihak ketiga yang independen yakni auditor dalam mengawasi perilaku manajemen untuk menghindari kecurangan tersebut (Praptitorini dan Januarti, 2007).

Salah satu KAP terbesar, yaitu KAP Arthur Andersen di Amerika Serikat turut bertanggung jawab atas kebangkrutan yang dialami Enron Corporation pada tahun 2001. KAP Arthur Andersen yang telah mengaudit lapokan keuangan Enron selama hampir 20 tahun tidak mampu mengungkap permasalahan keuangan yang dialami Enron dan secara sengaja maupun tidak sengaja ikut terlibat dalam konspirasi dengan Enron. Kasus tersebut mengakibatkan menurunnya kepercayaan publik atas independensi auditor (Giri, 2010).

Di Indonesia, hal serupa yang melibatkan auditor eksternal juga dialami PT Kimia Farma Tbk (PT KF). Kementerian BUMN dan Bapepam menemukan 
adanya salah saji dalam laporan keuangan PT KF yang mencantumkan lebih saji laba bersih untuk periode 31 Desember 2001 (Bapepam, 2002). Selain itu, manajemen PT KF juga melakukan pencatatan ganda atas penjualan unit usaha yang tidak disampling oleh auditor eksternal. Pada tahun tersebut, KAP yang mengaudit laporan keuangan PT KF adalah KAP Hans Tuanakotta \& Mustofa (HTM). Bapepam menyatakan HTM telah melakukan audit sampling sesuai dengan prosedur yang ada dalam Standar Profesional Akuntan Publik. Bapepam juga mengemukakan bahwa KAP Hans Tuanakotta \& Mustofa (HTM) tidak dengan sengaja membantu tindakan manajemen PT KF menggelembungkan keuntungannya, tetapi Bapepam menyimpulkan KAP HTM tidak mampu mendeteksi adanya penggelembungan keuntungan yang dilakukan PT KF.

Kasus-kasus tersebut telah meningkatkan perhatian pada pentingnya kualitas audit yang tercermin dari meningkatnya penelitian yang meneliti faktor-faktor yang berpengaruh terhadap kualitas audit. Salah satunya adalah Hansen et al. (2007) yang melakukan penelitian berkaitan dengan pengaruh workload atau audit capacity stress terhadap kualitas audit beberapa KAP di Amerika Serikat dikarenakan lonjakan jumlah klien baru setelah dibubarkannya KAP Arthur Andersen. Workload merupakan beban pekerjaan yang dimiliki oleh auditor. Jumlah rasio klien audit dan partner audit yang dimiliki suatu KAP yang bervariasi menenujukkan workload yang dimiliki tiap KAP berbeda-beda. Penelitian Lopez (2005) menemukan bahwa saat adanya tekanan workload, proses audit yang dilakukan akan menghasilkan kualitas audit yang lebih rendah dibandingkan ketika tidak adanya tekanan workload.

Selain permasalahan workload tersebut, skandal yang terkait KAP Arthur Andersen tersebut juga mendorong berbagai negara di dunia untuk menerbitkan peraturan baru mengenai masa perikatan audit. Peraturan ini dibuat untuk menghindari kecurangan dalam laporan keuangan yang melibatkan auditor. Aturan yang mengatur masa perikatan audit di Indonesia dapat ditemukan dalam Keputusan Menteri Keuangan Nomor 359/KMK.06/2003 tentang Jasa Akuntan Publik yang membatasi masa perikatan audit akuntan publik (AP) yaitu tiga tahun buku berturut-turut dan masa perikatan audit KAP adalah lima tahun buku berturut-turut. Peraturan tersebut sekarang telah diganti dengan PMK nomor 17/PMK.01/2008 yang menyebutkan pembatasan pemberian jasa KAP diperpanjang menjadi enam tahun berturut-turut.
Pembaruan peraturan mengenai masa perikatan akuntan publik dan kantor akuntan publik dengan klien dilakukan pemerintah untuk menghindari menurunnya independensi dan kompetensi auditor karena masa perikatan audit yang terlalu lama. Banyak perdebatan yang masih terjadi mengenai hubungan antara masa perikatan audit dan kualitas audit. Salah satunya yaitu penelitian Nasser et al. (2006) yang menemukan bahwa semakin panjang masa perikatan audit akan menurunkan independensi auditor karena munculnya hubungan emosional antara auditor dengan klien sehingga dapat mempengaruhi auditor dalam mengeluarkan opini audit. Penelitian tersebut bertentangan dengan penelitian Carcello dan Nagy (2004) yang menemukan bahwa kecurangan dalam laporan keuangan lebih sering terjadi pada masa awal perikatan audit.

Kasus yang terjadi pada perusahaan sebesar Enron memunculkan suatu tantangan dalam implementasi good corporate governance. Tidak hanya peran auditor eksternal yang diperlukan dalam menjamin kualitas audit perusahaan namun juga diperlukan pihak internal perusahaan yang bersifat independen dalam perannya mengawasi sistem pengendalian internal perusahaan yaitu komite audit. Menurut SK Bapepam dan LK No Kep 29/PM/2004, salah satu tugas komite audit adalah melakukan penelaahan atas informasi keuangan yang akan dikeluarkan perusahaan dan melakukan penelaahan atas pemeriksaan auditor eksternal.

Adanya komite audit diharapkan dapat mengurangi sifat opportunistic manajemen yang melakukan manajemen laba (earnings management) dengan cara pelaksanaan pengawasan terhadap laporan keuangan dan dapat membantu meningkatkan independensi auditor dengan adanya pengawasan terhadap auditor eksternal (Hamonangan dan Mas'ud, 2006). Lennox (2002) menyebutkan komite audit berperan penting dalam memberikan rekomendasi penunjukkan dan pergantian KAP dalam menjaga integritas proses pelaporan audit. Adanya temuan penelitian yang belum konsisten mengenai pengaruh masa perikatan audit terhadap kualitas audit menjadikan isu ini masih penting untuk diteliti dan perlunya penggunaan komite audit sebagai variabel moderasi. Penelitian ini menggunakan komite audit sebagai variabel moderasi mengacu pada penelitian Nuratama (2011) yang meneliti mengenai pengaruh interaksi komite audit sebagai variabel moderasi tenur KAP dan reputasi KAP terhadap kualitas audit. Penelitian ini menggunakan periode penelitian yang berbeda dan penggunaan variabel workload sebagai 
pengganti variabel reputasi KAP karena peneliti menemukan masih belum banyaknya informasi mengenai bagaimana tingkat workload pada masingmasing KAP di Indonesia dalam mempengaruhi kualitas audit KAP tersebut serta meneliti apakah komite audit berperan dalam membantu mengawasi kinerja auditor eksternal terkait dengan workload yang dimiliki KAP.

Berdasarkan penjabaran di atas, hipotesis yang diajukan sebagai berikut.

$\mathrm{H}_{1}$ : Workload Berpengaruh Negatif Terhadap Kualitas Audit.

$\mathrm{H}_{2}$ : Masa Perikatan Audit Berpengaruh Positif Terhadap Kualitas Audit.

$\mathrm{H}_{3}$ : Keberadaan Komite Audit Mampu Memoderasi Pengaruh Workload Terhadap Kualitas Audit

$\mathrm{H}_{4}$ : Keberadaan Komite Audit Mampu Memoderasi Pengaruh Masa Perikatan Audit Terhadap Kualitas Audit.

\section{METODE PENELITIAN}

Jenis data yang digunakan pada penelitian ini adalah data kuantitatif dan data kualitatif. Penelitian ini menggunakan data sekunder yang berupa laporan KAP yang dikirim ke Pusat Pembinaan Akuntan dan Jasa Penilai (PPAJP) Kementerian Keuangan RI serta laporan tahunan dan laporan keuangan perusahaan yang dapat diakses melalui situs BEI yaitu www.idx.co.id. Metode purposive sampling digunakan untuk memperoleh sampel pada perusahaan dari sektor manufaktur dengan beberapa kriteria. Adapun kriteria yang diajukan yaitu: 1) perusahaan manufaktur yang terdaftar di BEI berturutturut tahun 2010-2012; 2) menyajikan laporan keuangan dalam rupiah; 3) berdasarkan KAP terdaftar tahun 2012 yang mengaudit perusahaan di sektor manufaktur, apabila KAP tersebut hanya mengaudit satu perusahaan di sektor manufaktur, maka perusahaan yang diaudit tersebut langsung dijadikan sampel; 4) berdasarkan KAP terdaftar tahun 2012 yang mengaudit perusahaan di sektor manufaktur, apabila KAP tersebut mengaudit beberapa perusahaan di sektor manufaktur, maka dipilih perusahaan dengan aset terbesar untuk dijadikan sampel. Beberapa kriteria tersebut menghasilkan 31 sampel data selama periode 1 tahun.

Variabel independennya yaitu variabel workload diukur menggunakan model yang digunakan Liswan dan Fitriany (2012).

Variabel masa perikatan audit diukur dengan menghitung tahun KAP yang sama telah melakukan perikatan dengan auditee dengan penggunaan skala interval dimana untuk tahun pertama perikatan dimulai dengan angka 1 dan ditambah satu untuk tahun berikutnya apabila KAP mengaudit klien yang sama. Jika ada perubahan afiliasi, maka perhitungan masa perikatan audit akan dimulai dari awal.

Variabel dependennya adalah kualitas audit menggunakan proksi akrual lancar dengan menggunakan model yang dikembangkan Myers et al. (2003). Variabel moderasi: komite audit diukur berdasarkan ukurannya dengan rumus yang digunakan sesuai dengan penelitian Nuratama (2011).

Teknik analisis data yang digunakan yaitu Moderated Regression Analysis (MRA). Pengujian regresi dalam penelitian ini melalui tahapan yaitu: 1) menilai statistik deskriptif, 2) uji asumsi klasik yang melalui tiga jenis pengujian: uji normalitas, uji autokorelasi, uji heteroskedastisitas, 3 ) uji statistik F (uji signifikansi simultan), 4) uji Moderated Regression Analysis (MRA), dan 5) uji t (uji signifikansi parsial).

$$
\text { Workload }=\frac{\text { Jumlah klien audit suatu KAP pada tahun tersebut }}{\text { Jumlah partner di KAP pada tahun tersebut }}
$$

$$
\text { AKRUALLANCAR }=(\triangle A L-\triangle K A S)-(\triangle L L-\triangle L J P)
$$

Keterangan:

"AL = perubahan dari aset lancar

"KAS = perubahan dari kas dan ekuivalen kas

"LL = perubahan dari liabilitas lancar

"LJP = perubahan dalam utang wesel jangka pendek dan utang jangka panjang yang akan jatuh tempo

$$
\text { Persentase keberadaan komite audit }=\frac{\text { jumlah komite audit }}{\text { jumlah komisaris }}
$$




\section{HASIL DAN PEMBAHASAN}

Berdasarkan dari kriteria sampel yang digunakan maka diperoleh 31 sampel data selama periode 1 tahun. Hasil uji statistik terlihat pada Tabel 1.

Pengujian uji asumsi klasik yang dilalui penelitian ini yaitu uji normalitas, uji heteroskedastisitas, dan uji autokorelasi. Hasil uji statistik menyatakan penelitian ini telah lolos dari ketiga jenis uji asumsi klasik tersebut. Selanjutnya penelitian ini melalui uji kelayakan model atau dengan kata lain disebut Goodnes of Fit dan hasil pengujian ini sesuai dengan yang disajikan pada Tabel 2.
Uji F yang dilalui penelitian ini menghasilkan nilai signifikansi sebesar 0,000 yang lebih kecil dari nilai 0,005 maka dari hasil ini dapat dikatakan bahwa model penelitian ini layak atau fit. Pada Tabel 2 nilai adjusted $R$ square sebesar 0,619 menunjukkan bahwa variabel bebas dalam penelitian ini memiliki pengaruh sebesar 61,9 persen pada variabel terikatnya, sisanya 38,1 persen dipengaruhi oleh variabel lainnya.

Pengujian hipotesis penelitian ini menggunakan Moderated Regression Analysis (MRA). Hasil dari pengujiannya disajikan pada Tabel 3.

Tabel 1.

Statistik Deskriptif

\begin{tabular}{lrrrrrr}
\hline & N & Minimum & Maximum & Modus & Mean & $\begin{array}{c}\text { Std. } \\
\text { Deviation }\end{array}$ \\
\hline Workload (X1) & 31 & .0095 & 1.3867 & - & .438 & .3064 \\
Masa Perikatan Audit & 31 & 1 & 3 & 3 & 2.129 & .8848 \\
(X2) & & & & & & \\
Komite Audit (X3) & 31 & .231 & 1.5 & 1 & .819 & .4046 \\
Akrual Lancar(Y) & 31 & -.7888 & 5.751 & - & .694 & 1.4592 \\
Valid N (listwise) & 31 & & & & & \\
\hline
\end{tabular}

Sumber: Data Diolah, 2015

Tabel 2.

Uji Simultan (Uji F)

\begin{tabular}{|c|c|c|c|c|c|c|}
\hline & Model & Sum of Squares & Df & $\begin{array}{c}\text { Mean } \\
\text { Square }\end{array}$ & $\mathrm{F}$ & Sig. \\
\hline \multirow[t]{3}{*}{1} & Regression & 43.626 & 5 & 8.725 & 10.766 & $.000^{\mathrm{a}}$ \\
\hline & Residual & 20.261 & 25 & .810 & & \\
\hline & Total & 63.886 & 30 & & & \\
\hline \multicolumn{7}{|c|}{$\mathrm{R}=0,826^{\mathrm{a}}$} \\
\hline \multicolumn{7}{|c|}{$\mathrm{R}$ square $=0,683$} \\
\hline \multicolumn{7}{|c|}{ Adjusted R Square $=0,619$} \\
\hline \multicolumn{7}{|c|}{ Std. Error estimate $=0,9002361$} \\
\hline
\end{tabular}

Sumber: Data Diolah, 2015

Tabel 3.

Hasil Pengujian Hipotesis

\begin{tabular}{|c|c|c|c|c|}
\hline Mod 1 & $\begin{array}{c}\begin{array}{c}\text { Unstandardized } \\
\text { Coefficients }\end{array} \\
\mathrm{B}\end{array}$ & $\mathrm{t}$ & Sig. & Keterangan \\
\hline 1 (Constant) & 2.960 & 2.371 & .026 & \\
\hline Workload (X1) & 7.442 & 5.629 & .000 & sig. positif \\
\hline Masa Perikatan Audit (X2) & -2.093 & -3.921 & .001 & sig. negatif \\
\hline Komite Audit (X3) & -2.486 & -2.090 & .047 & sig. negatif \\
\hline $\begin{array}{l}\text { Workload (X1) * Komite } \\
\text { Audit (X3) }\end{array}$ & -4.735 & -3.940 & .001 & sig. negatif \\
\hline $\begin{array}{l}\text { Masa Perikatan Audit (X2) * } \\
\text { Komite Audit (X3) }\end{array}$ & 1.611 & 2.832 & .009 & sig. positif \\
\hline
\end{tabular}

Sumber: Data Diolah, 2015 
Pengujian hipotesis pertama menghasilkan tingkat signifikansi dari variabel workload senilai 0,000 yang menunjukkan nilai signifikansinya lebih rendah dari $\alpha=0,05$ ini berarti workload berpengaruh signifikan pada akrual lancar. Nilai koefisien variabel workload sebesar 7,442 yang berarti variabel workload mendukung hipotesis pertama. Workload berpengaruh positif pada akrual lancar (berpengaruh negatif pada kualitas audit). Arah positif ini menandakan semakin meningkatnya workload berpengaruh dalam meningkatkan akrual lancar (menurunkan kualitas audit). Lopez (2005) dan Fitriany (2011) menemukan bahwa workload berpengaruh negatif pada kualitas audit karena proses audit yang dilakukan saat terjadinya workload akan menghasilkan kualitas audit yang lebih rendah dibandingkan saat tidak adanya tekanan workload karena dikhawatirkan tingginya workload akan menimbulkan kelelahan bagi auditor dan menurunkan konservatisme dan kemampuan auditor dalam menemukan maupun melaporkan kekeliruan atau salah saji material dan penyimpangan yang terdapat dalam laporan keuangan. Hal tersebut kemudian meningkatkan risiko audit yang tercermin dari ketidakmampuan auditor mendeteksi secara akurat praktik kecurangan yang mungkin terjadi seperti earnings management yang dapat dilihat dari tingkat akrual yang tinggi.

Pengujian hipotesis kedua menghasilkan tingkat signifikansi dari variabel masa perikatan audit senilai 0,001 yang menunjukkan nilai signifikansinya lebih rendah dari $\alpha=0,05$ ini berarti masa perikatan audit berpengaruh signifikan pada akrual lancar. Nilai koefisien variabel masa perikatan audit sebesar -2,093 yang berarti variabel masa perikatan audit mendukung hipotesis kedua. Masa perikatan audit berpengaruh negatif pada akrual lancar (berpengaruh positif pada kualitas audit). Arah negatif ini menandakan semakin meningkatnya masa perikatan audit akan menurunkan akrual lancar (meningkatkan kualitas audit). Pada penelitian Nuratama (2011) masa perikatan KAP menghasilkan pengaruh positif pada kualitas audit disebabkan karena seiring bertambah lamanya masa perikatan antara auditor dengan kliennya menyebabkan bertambahnya pengetahuan dan pengalaman yang dimiliki auditor yang dapat digunakan untuk merancang prosedur audit yang lebih efektif. Selain itu, dengan bertambahnya masa perikatan audit maka akan semakin meningkatkan pengetahuan auditor mengenai proses bisnis klien.

Hasil pengujian hipotesis ketiga menghasilkan signifikansi dari variabel interaksi (workload*komite audit) senilai 0,001 yang berarti lebih rendah dari $\alpha$
$=0,05$ maka hal ini menandakan interaksi antara komite audit dan workload mendukung hipotesis ketiga $\left(\mathrm{H}_{3}\right)$. Koefisien dari variabel interaksi workload dan komite audit yaitu sebesar $-4,735$ menunjukkan pengaruh dengan arah negatif pada akrual lancar (positif pada kualitas audit). Hal ini berarti moderasi variabel komite audit memperlemah hubungan negatif workload terhadap kualitas audit. Hal ini berarti semakin tinggi proporsi keberadaan komite audit akan mampu mengurangi pengaruh negatif workload terhadap kualitas audit. Komite audit yang independen dan aktif akan cenderung memilih KAP yang memiliki workload yang rendah. Tujuan dari pemilihan auditor tersebut adalah untuk menghindari hubungan mutualistik yang dapat menurunkan independensi auditor dan mencegah terjadinya penurunan kemampuan auditor dalam menemukan kekeliruan dalam laporan keuangan yang disebabkan workload yang dialami auditor.

Hasil dari pengujian hipotesis keempat menghasilkan tingkat signifikansi dari variabel interaksi (masa perikatan audit*kualitas komite audit) sebesar 0,009 yang berarti lebih kecil dari $\alpha=0,05$, hal ini menandakan bahwa interaksi antara komite audit dan masa perikatan audit mendukung hipotesis keempat $\left(\mathrm{H}_{4}\right)$. Koefisien dari variabel interaksi masa perikatan audit dan komite audit adalah sebesar 1,611 hal ini berarti moderasi masa perikatan audit dan komite audit menghasilkan arah pengaruh positif pada akrual lancar (arah negatif pada kualitas audit). Hal ini berarti moderasi variabel komite audit memperlemah hubungan positif masa perikatan KAP terhadap kualitas audit. Semakin tingginya proporsi keberadaan komite audit akan berpengaruh pada semakin pendeknya masa perikatan antara KAP dengan kliennya. Hal ini disebabkan karena adanya kemungkinan semakin tingginya proporsi keberadaan komite audit maka akan menyebabkan semakin efektifnya komite audit dalam menjalankan tugasnya saat mengawasi auditor eksternal. Untuk mempertahankan independensi auditor maka komite audit akan cenderung memperpendek masa perikatan audit yang bertujuan untuk mencegah hubungan keakraban di antara auditor dan klien. Komite audit akan cenderung memilih auditor baru yang diharapkan lebih independen karena auditor yang baru dianggap tidak memiliki kedekatan dengan pihak manajemen perusahaan. Hasil penelitian ini mendukung penelitian Nuratama (2011) yang menemukan variabel interaksi masa perikatan audit dan komite audit berpengaruh dalam menurunkan kualitas audit. 


\section{SIMPULAN}

Berdasarkan penjabaran sebelumnya maka dapat ditarik simpulan bahwa variabel workload berpengaruh negatif pada kualitas audit. Semakin tinggi workload akan menurunkan kualitas audit, kondisi ini terjadi karena semakin tinggi workload akan menurunkan kemampuan auditor dalam menemukan maupun melaporkan kekeliruan dan penyimpangan yang terdapat dalam laporan keuangan. Masa perikatan audit berpengaruh positif pada kualitas audit yang berarti bahwa semakin lamanya suatu KAP melakukan perikatan dengan kliennya akan meningkatkan kualitas audit. Pengaruh positif tersebut terutama disebabkan karena semakin lamanya masa perikatan audit maka KAP akan memiliki pengetahuan yang lebih baik mengenai proses bisnis klien sehingga dapat merancang prosedur audit yang lebih efektif. Komite audit sebagai variabel moderasi mampu memperlemah pengaruh negatif workload terhadap kualitas audit melalui perannya dalam pemilihan KAP karena komite audit yang independen dan aktif akan cenderung memilih KAP yang memiliki workload rendah untuk mencegah terjadinya penurunan kemampuan auditor dalam menemukan kekeliruan dalam laporan keuangan. Variabel interaksi antara masa perikatan audit dan komite audit berpengaruh dalam memperlemah pengaruh masa perikatan audit terhadap kualitas audit. Komite audit akan cenderung memperpendek masa perikatan audit dan memilih auditor baru yang diharapkan lebih independen karena auditor yang baru dianggap tidak memiliki kedekatan dengan pihak manajemen perusahaan

Saran yang dapat disimpulkan dari penelitian ini adalah bagi KAP perlu mempertimbangkan beban kerja auditor dan mematuhi sistem pengendalian mutu yang dijadikan pedoman dalam pelaksanaan audit. Bagi perusahaan, proporsi keberadaan komite audit dalam perusahaan perlu ditingkatkan karena komite audit dengan jumlah anggota yang tepat dapat membuat anggota komite audit menggunakan pengalaman dan keahlian yang dimiliki untuk melaksanakan tugasnya secara efektif. Saran untuk peneliti selanjutnya dapat meneliti faktor-faktor yang mempengaruhi kualitas audit pada sampel yang berbeda dan mempertimbangkan proksi yang berbeda untuk mengukur komite audit, ukuran lain dapat berupa skoring untuk menilai kualitas komite audit. Nilai adjusted $R$ square dalam penelitian ini sebesar 0,619, ini berarti 38,1 persen variasi dalam kualitas audit dipengaruhi oleh variabel-variabel yang tidak dimasukkan ke dalam model penelitian ini. Untuk itu kepada peneliti selanjutnya dapat disarankan untuk meneliti pengaruh variabel-variabel lain seperti rotasi audit, spesialisasi auditor, dan ukuran KAP.

\section{REFERENSI}

Badan Pengawas Pasar Modal (Bapepam). 2002. Siaran Pers Badan Pengawas Pasar Modal, 27 Desember 2002.

Carcello, Albert L, Joseph V., Nagy. 2004. Audit Firm Tenure and Fraudulent Financial Reporting. University of Tennessee.

Carey, Peter. Simnett, Roger. 2006. Audit Partner Tenure and Audit Quality. The Accounting Review.

Fitriany dan Junius. 2011. Pengaruh Audit Capacity Stress, Pendidikan Profesi Lanjutan, Ukuran KAP dan Spesialisasi Terhadap Manajemen Laba Akrual dan Manipulasi Aktivitas Riil. Universitas Indonesia.

Giri, Efraim F., 2010. Pengaruh Tenur Kantor Akuntan Publik dan Reputasi KAPTerhadap Kualitas Audit: Kasus Rotasi Wajib Auditor Di Indonesia. Simposium Nasional Akuntansi XIII. Purwokerto.

Hamonangan Siallagan., Mas'ud Machfoedz. 2006. Mekanisme Corporate Governance, Kualitas Laba dan Nilai Perusahaan. Simposium Nasional Akuntansi 9.

Hansen C. S, Sullivan M. W. and Kumar K. R. 2007. Auditor Capacity Stress and Audit Quality: MarketBased Evidence from Andersen's Indictment. Journal of Accounting and Economics, 10-49.

Jensen, M.C. and W.H. Meckling. 1976. Theory of The Firm: Managerial Behaviour Agency Cost and Ownership Structure. Jurnal Of Finance Economic. Vol 3, No. 4:305-360

Kementerian Keuangan RI. Keputusan Menteri Keuangan Republik Indonesia Nomor 359/ KMK.06/2003 Tentang Perubahan Atas Keputusan Menteri Keuangan Nomor 423/ KMK.06/2002, Tentang Jasa Akuntan Publik.

Kementerian Keuangan RI. Peraturan Menteri Keuangan Republik Indonesia Nomor 17/PMK.01/ 2008, Tentang Jasa Akuntan Publik.

Koroy, Tri Ramaraya. Pendeteksian Kecurangan (Fraud) Laporan Keuangan oleh Auditor Eksternal. STIE Nasional Banjarmasin Indonesia.

Lennox, Clive. S, 2002. Opinion Shopping and Audit Committees. CEI Working Paper Series, No. 200212.

Lopez-Aceveco, D. M. 2005. The Effect of Workload Compression on Audit Quality. Working Paper, University of Arkansas. 
Manry, D. L., T. J. Mock, and J.L. Turner. 2008. Does Increased Audit Partner Tenure Reduce Audit Quality? Journal of Accounting, Auditing \& Finance: 553-572.

Myers, James N., Linda A., and Omer, Thomas C. Omer. 2003. Exploring the Term of the AuditorClient Relationship and the Quality of Earnings: A Case for Mandatory Auditor Rotation? The Accounting Review 78 (3), 779-799.

Nasser, Abdul and Emelin Abdul Wahid. 2006. AuditorClient Relationship ; the case of audit tenure and auditor swicthing in Malaysia. Managerial Auditing Journal, Vol 21, No 7.

Nuratama, I Putu. 2011. Pengaruh Tenur Dan Reputasi Kantor Akuntan Publik Pada Kualitas Audit Dengan Komite Audit Sebagai Variabel Moderasi (Studi Kasus Pada Perusahaan Manufaktur Yang
Terdaftar Di BEI Tahun 2004-2009). Tesis, Program Pasca Sarjana Universitas Udayana.

Praptitorini, Mirna Dyah dan Indira Januarti. 2007. Analisis Pengaruh Kualitas Audit, Debt Default, dan Opinion Shopping terhadap Penerimaan Opini Going Concern. Disampaikan pada Simposium Nasional Akuntansi (SNA) X Makassar.

Salno, H dan Zaki Baridwan. 2000. Analisis Perataan Penghasilan (Income Smoothing), Faktor-faktor yang Memengaruhi dan Kaitannya dengan Kinerja Saham Perusahaan Publik di Indonesia, Jurnal Riset Akuntansi Indonesia, Vol 3, No 1, Januari, h. 17-34

Setiawan W., Fitriany dan Liswan. 2011. Pengaruh Workload dan Spesialisasi Auditor Terhadap Kualitas Audit dengan Kualitas Komite Audit sebagai Variabel Pemoderasi. Universitas Indonesia. 